泱していこうとするものである。しかしながら，HIV 感染症, エイズはSTDでもあり，不治の病でるあ る.そして，この歷史の浅い疾患には，偏見之差別がつ きまとっている.したがって，HIV/エイズカウンセリン グは, 病名告知, 発病, 二次感染, ターミナルケアー, 社会的対応など多様かつ深刻な場面を担当しなければな らない。

HIV 感染が，異性間性交涉を介乙て急速に広まりつつ 西る現在，職域に打行る対応も，㤵蒙・啓発活動，検查 体制の充実，医療機関の整備，エイズ教育などの対策と 並んで，きわめて重要なるのとなってきている．職域に おける HIV/エイズカウンセリングは，大きく分けて，

1) HIV 感染を恐れる人への援助（教有，カウンセリン グ，抗体検查の衔少等）と 2）感染者, 患者への援助 （カウンセリング，生活・人権の保護，勤務上の配虑 等）があるであるら、ここで，カウンセリングといらも のについて馿染みが薄いわが国では，「カウンセリング とは, 感染者, 患者 (来談者, 相談者, クライエント) の心の問題を, クライェント自身が自分で解決していく のを援助する」ことであるということをまず確認してお く必要がある.そのカウンセリングを施すカウンセラー は，医師，看護婦とは異なった専門的知識と技術孝有乙 ているが，残念ながら医療，保健，福祉，産業の中で活 躍するカウンセラーはまだ少ない，したがって，医師， 看護婦，保健婦が，カウンセリングの心構觉を持ってク ライエントと接することが重要である.これをカウンセ リングマインドと呼ら゙が，決して高度な技術や知識を要
求するむのではない，クライエントのために，時間と空 間を確保して，真㓱に耳を傾ける気持らがあればまず は，カウンセリングマインドのスタートであある。相手 の気持らになって考光, 問題解決のための「指示」では なくあくまでも「支持」していくことを貫くことが肝 要である.

\section{5. 司会者のまとめ}

鉡倉光宏（度応大医衛生公衛）

4 人の演者の講演終了後，会場上りの質問を受けた が，まずエイズ予防財団専務理事山形操六氏より，外資 系企業に政るコンサルティング・システムと日系企業 に扰ける守秘，特炕 HIV 抗体陽性者が継続的に免疫機 能を測定して行った場合などに捣けるレセプト取报い者 の守秘義務の問題についての質問が，それぞれ森晃爾氏 と浜口伝博氏に対してあった。何れも制度としての整備 はなされていないが，今後個々の事例に対しては慎重な 対応が必要であるといら意見であった，次いで，ソニー (株) 健康開発センター長福井俊夫氏より，検査の結果 HIV 抗体陽性の社員から産業医が相談を受けた時，その 後の対応を行う上で，具体的な医療行為が「後天性免疫 不全症候群の予防に関する法律」（いわゆるエイズ予防 法）の守秘性に関する罰則規定と抵触する可能性はない かとの質問があった．シンポジストの稲坦稔氏より，患 者が産業医に積極的飞援助を求めている場合，医師のほ らも通常の医療行為に則して，守秘性に留意しながら患 者の紹介・健康管理等の治療行為を行らことに特問題 はないとのことであった。

\section{第 21 回職業性アレルギー研究会*}

\section{<特別講演 $>$}

\section{1. 職業性過敏性肺炎の症例とその抗原の同定} 吉田和子 (熊本大内科公衛)

過敏性肺炎 (HP) 飞和いてて，原因抗原の決定は，診断 治療のために不可欠である.我々はこれまでに，発症環 境に括汗る真菌学的検討から，わが国の HP の $3 / 4$ を占 める夏型過敏性肺炎について原因抗原を明らかにし，環 境改善対策による原因療法を可能にした，今回その方法 の応用によって，4例の興味深い職業性 HP の原因抗原

*1993 年 5 月 6 日 (木) $18 \sim 20$ 時，バシフィコ横浜（第 311 号会諻室)

世話人：野村 茂（労研），大前和幸（度店大医衛生公衛）
を同定し光たのでここに報告し，環境からの原因抗原同 定法之，各抗原の意義について考察する。

[対象之方法] 病歷, 臨床像, 病理学的所見から，職 業性 HP を疑われた 4 症例を対象に，1）作業環境曝露 による誘発試験，2）作業環境下での菌の分離，3）塵 埃，分離菌の患者血清汇対する間接営光抗 体 価測 定,

4）抗原作製，毒性試験，5）沈降抗体測定，皮内テス ト, リンパ球奻若化試験，6）吸入誘発試験，7）㻴境 改善による原因抗原の除去を施行した。

[結果之考察] 各症例飞ついて，以下の原因抗原が同 定された. 症例 1 ：光のき茸栽培者；低温栽培室（7〜 $\left.18^{\circ} \mathrm{C}\right)$ で発育良好な Aspergillus glaucus とよる栽培容

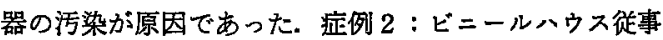
者；ビニールハウスの高温環境 $\left(50^{\circ} \mathrm{C}\right.$ 以上) で発育良好 な A. fumigatus が堆肥から多量保出された。症例 3：肥後象峐職人；製作工程で使用していた菰墨が原因 
であり、これは真菌 Ustilago esculenta の厚膜胞子と同 定された。症例 4 : 畜虚從事者; 飼料火增殖したCandida albicans，も乙くは C. guilliermondii による慢性 HP 例と考光られた.

以上はここに示した職業のみではなく，異なった環 境に颃いても原因抗原となっている可能性があり，今後 注意が必要である. また，職業性 HP の診断や予防に は，このような個々の症例の原因抗原同定の積み重ねが 重要であると考えられる。

\section{2. 成人気管支喘息の実態と動向}

$$
\begin{array}{r}
\text { 前田裕二（国立相模原病院アレルキ゚ー } \\
\text { センター臨床研究部内科） }
\end{array}
$$

気管支喘息の現解と新しい薬物の開発が進んでいるに る関わらずこの30 年間で喘息の䍜患率は 3 倍の約 $3 \%$ まで増加し，死亡率も 10 万詨約 $5 \%$ と高率である. 事 情は欧米であ同じであり 92 年には米国 NIH を中心に 欧米各国が集まり喘息の診断と治療のための国際委員会 が催されガイドラインが報告された．かが国でもこれに 先立ち 90 年に全国 31 病院, 2,927 名の成人喘息患者の 実態調査がなされた，その成績は発症時期では小児発 症 11.1 , 成人再発 3.7 , 成人発症 $77.3 \%$ であった. 40 歳以上の患者ではその 8 割が成人発症であり加龄と共に 成人発症は増加する. 成人発症は小児発症に比べ感染 型, アスピリン過敏, 薬剤の常用, 重症例が多かった. これに比し小児発症では男, アトピー型, 軽症が多かっ たが夜間外来，酸素投与，人工呼吸器使用例多多く，喘 息死の危険が高い群である可能珄が示俊された，人工呼 吸器使用例は $4.8 \%$, 経験のない例は $95.2 \%$ であった. その背景因子を比較すると使用例では小児喘息歴があ り, 通年十季節性に発作があり常時服薬し, 重症とされ, 公害医療の適用を受けている例が多いという結果が得ら れた。

最近，気管支喘息は好酸球性の慢性気管支炎であると いら概念で珿えるようになり，国際委員会報告でる吸入 性ステロイド（吸ス剂）を中等症以上の例の第一選択剤 としている.わが国です吸ス剂の使用は施設により患者
への使用率は 0〜33\%といらようにかなりの幅がみられ る. 吸不剤を多用している施設とス郕をあまり使用しな い施設群で喘息死の危険が高いと考兄られる人工呼吸器 使用例の割合を見ると吸ス剂多用施設でる吸ス剂をあま り使用しない施設でも4\%とその割合には差は見られな かった.このことは喘息死を防ぐためには単に吸ス剤に よる炎症の抑制のみでは充分でない可能性を示してい る. 報告で述べているピークフローによる自己管理を始 めとし，患者の発作管理計画が実際にどれはどの効果を 上げるかこれから注目すべき点であるら。

\section{$<$ 特別報告>}

研究会 20 回の歩みを顧みて

野村 茂 (労研)

日本産業衛生学会の研究会活動の一つとして, 第 1 回 の本研究会が開催されたのは，1976 年6月12 日(土), 大阪府立学働会館においてであった，その後会を重水 16 年を経て，1993年（平成 5 年）1月 30 日に，特別企 画として第 20 回研究会が名古屋市において愛知県医師 会の媵援で盛大に開催された。

そこで，「免疫アレルギー学研究の新しい展望」のテ ーマで企画されたこの研究会に和いて私の行った同主題 の報告内容の概要を今回の研究会でも紹介したい，

まず，日本での職業性アレルギ一研究の発展と現状に ついて医学の各領域で,これがどのように取り上げら れてきたか、そしてその関連において，本研究会は何を やって来たのかを回顧した. そして，本研究会で討論さ れ，諎学会や行政にも反映された成果として次のよらな むのを例示紹介した，すなるち，TDI ペリリウムによる 呼吸器, 皮膚のフレルギーと健康管理, 硬合金とアレル ギ一機作，感作性物質の許容濃度についての調查研究， 職業性花粉症の成因之対策, 感作性物質の予知と安全試 験，農業に和けるアレルギー性疾患などである。

そして，このような研究会の歩みを踏まえて，本研究 会が如何にあるべきか, 今後の課題と研究会運営につい ても言及した。 